Article

\title{
Evaluation of Anti-Tumorigenic Effects of Diosmetin against Human Colon Cancer Xenografts in Athymic Nude Mice
}

\author{
Sanaz Koosha, Zahurin Mohamed, Ajantha Sinniah and Mohammed A. Alshawsh *(1) \\ Department of Pharmacology, Faculty of Medicine, University of Malaya, Kuala Lumpur 50603, Malaysia \\ * Correspondence: alshaweshmam@um.edu.my; Tel.: +60-3-7967-4950
}

Received: 18 March 2019; Accepted: 26 April 2019; Published: 10 July 2019

\begin{abstract}
Colon cancer is the third most common type of cancer in the world. Diosmetin (Dis), a natural $O$-methylated flavone, has been reported to have anti-cancer effects against different types of cancer. Although the mechanisms of action of Dis against several cancer cell lines are well reported, in vivo anti-tumorigenesis properties of this compound are still obscure. Therefore, this study aimed to investigate the anti-tumorigenesis properties of Dis against HCT-116 colon cancer xenografts in nude mice. HCT-116 colon cancer cells were injected in $\mathrm{NCr}$ nu/nu nude mice and treatment with Dis was initiated after the tumor volumes reached $100 \mathrm{~mm}^{3}$ and continued for four weeks. On the sacrificing date nude mice treated with $100 \mathrm{mg} / \mathrm{kg}$ of Dis showed significant lower tumor volume (264 $\left.\pm 238.3 \mathrm{~mm}^{3}\right)$ as compared to the untreated group $\left(1428.8 \pm 459.6 \mathrm{~mm}^{3}\right)$. Anti-apoptotic Bcl-2 protein was significantly downregulated, while apoptotic protein (Bax) was significantly overexpressed in nude mice treated with $100 \mathrm{mg} / \mathrm{kg}$ Dis as compared to untreated mice. In conclusion, our in vivo results indicate that Dis significantly reduces tumor growth rate of HCT-116 colon cancer cells in nude mice at a dose of $100 \mathrm{mg} / \mathrm{kg}$, and has no toxic effects in ICR mice up to $2000 \mathrm{mg} / \mathrm{kg}$.
\end{abstract}

Keywords: colon cancer; diosmetin; anti-tumorigenesis; apoptosis; nude mice

\section{Introduction}

Colon cancer (CRC) is the third leading cause of cancer mortality in the world with increasing trends in incidence and mortality rate [1]. Current chemotherapy drugs for CRC such as oxaliplatin and 5-fluorouracil (5-Fu) come with a variety of undesirable side effects such as diarrhea, bone marrow suppression, peripheral neuropathy and cardiotoxicity [2]. In recent decades, natural products have attracted attention as potent candidates to combat cancer due to their anti-cancer efficacy and low side effects [3].

Diosmetin (Dis) is an O-methylated flavone that can be extracted from citrus and other medicinal plants. Dis inhibits proliferation of several cancer cell types such as hepatocarcinoma, leukemia, breast, lung and prostate [4-8]. Dis inhibits cell cycle progression in mitosis phase due to suppression of polo-like kinase 1 (PLK1) factor [4]. Several studies have confirmed that proliferation of A549, MDA-MB 468, LNCaP and PC3 cancer cells are inhibited by Dis at G0/G1 phase of the cell cycle [5-8]. In addition to inhibition of cell proliferation and metastasis, Dis inhibits matrix metalloproteinases (MMP 2 and MMP 9) in hepatocellular carcinoma (HCC) cells [9].

Other than inhibition of metastasis and cell proliferation, Dis induces apoptosis in prostate cancer cells through over expression of Bax, p27kip1 and Foxo3 and down regulation of Bcl-2 and c-Myc [6]. Induction of apoptosis in leukemia and hepatocarcinoma cells occur through activation of extrinsic apoptosis pathway and inhibition of NF- $\mathrm{kB}$ and activation of p53, respectively [8,10,11]. Dis showed cytotoxic effects against various colon cancer cell lines such as Caco-2, HT-29 and Colo205 [12-14]. 
The study was carried out in our lab to assess the mechanistic signaling pathways underlying the anti-proliferative and apoptosis properties of Dis against HCT-116 colon cancer cells (in vitro). This demonstrated that Dis mediates the disruption of mitotic associated genes and cyclin $\mathrm{A} / \mathrm{B}$ and induces apoptosis via inhibition of NF- $\mathrm{kB}$ translocation and upregulation of apoptotic factors including Fas and Bax of Dis on different cancer cell lines, the anti-tumorigenesis properties of Dis in an animal model needs to be explored to confirm in vitro findings. In the present study, the in vivo safety level of Dis was investigated through acute toxicity study. In addition, the anti-tumorigenic activity of Dis was evaluated against human colon cancer cells (HCT-116) xenografts in nude mice.

\section{Results}

\subsection{Acute Toxicity of Diosmetin}

The acute toxicity test of Dis on female ICR mice did not demonstrate any signs of toxicity or mortality in the treated animals during the 14 days of observation after the oral administration of a single dose of $300 \mathrm{mg} / \mathrm{kg}$ and $2000 \mathrm{mg} / \mathrm{kg}$ of Dis. Moreover, no abnormal behavior such as changes in eyes, fur, skin, respiration, sedation, and convulsion were observed within 14 days. There were no significant changes in body weight between treated and untreated mice (Figure 1A). Furthermore, no abnormality was observed in the histopathology of the liver or the kidney of any of the mice (Figure 1B). No signs of inflammation were observed in the liver of treated and untreated mice as demonstrated by absence of lymphocytes accumulation around the hepatic vein. Cell walls were intact in both kidney and liver tissues and no signs of necrosis were observed. Kidney glomeruli were normal and no sign of kidney damage was observed in treated and control groups (Figure 1B).

\subsection{Dis Reduces Tumor Size in HCT-116 Colon Cancer Xenograft Nude Mice}

To investigate the anti-tumorigenic properties of Dis, HCT-116 cancer cells were injected into the right flank of Ncr nu/nu mice subcutaneously. After the tumor volume reached $100 \mathrm{~mm}^{3}$, mice were orally administered with vehicle or Dis at dose of 50 and $100 \mathrm{mg} / \mathrm{kg}$ of body weight for four weeks. The positive control group received $30 \mathrm{mg} / \mathrm{kg}$ of 5-Fu intraperitoneally as a standard drug. Results of the tumor tissue indicate that Dis suppress the development of tumor in nude mice. As shown in Figure 2 the tumor size of Dis and 5-Fu treated mice were smaller as compared to the untreated group. Final tumor volume on the sacrificing date of $5-\mathrm{Fu}, 50 \mathrm{mg} / \mathrm{kg}$ and $100 \mathrm{mg} / \mathrm{kg}$ of Dis were $340 \pm$ $175.5 \mathrm{~mm}^{3}, 581.7 \pm 266 \mathrm{~mm}^{3}$ and $264 \pm 238.3 \mathrm{~mm}^{3}$, respectively, which were significantly smaller as compared to the untreated group $\left(1428.8 \pm 459.6 \mathrm{~mm}^{3}\right)$ (Figure 3A,B). Area under the curve (AUC) of each group was measured and compared to the untreated group in order to monitor the tumor growth rate during the 27 days of treatment. As shown in Figure 3C, treatment with $50 \mathrm{mg} / \mathrm{kg}$ and $100 \mathrm{mg} / \mathrm{kg}$ of Dis significantly reduced tumor volume growth rate from $20647 \pm 5653$ in control group to $8131 \pm$ $2988(p<0.05)$ and $6009 \pm 3788(p<0.01)$, respectively. AUC of 5-Fu group showed that tumor growth rate of mice treated with the standard drug $(6270 \pm 2698)$ was slightly higher as compared to the high dose of Dis $(100 \mathrm{mg} / \mathrm{kg})$.

Based on the tumor ratio percentage formula, $100 \mathrm{mg} / \mathrm{kg}$ of Dis has the lowest tumor growth $(22.3 \%)$, followed by 5 -Fu group $(27.4 \%)$ and $50 \mathrm{mg} / \mathrm{kg}$ of Dis $(43.5 \%)$. These data suggest that Dis inhibits tumor growth rate dose-dependently. 

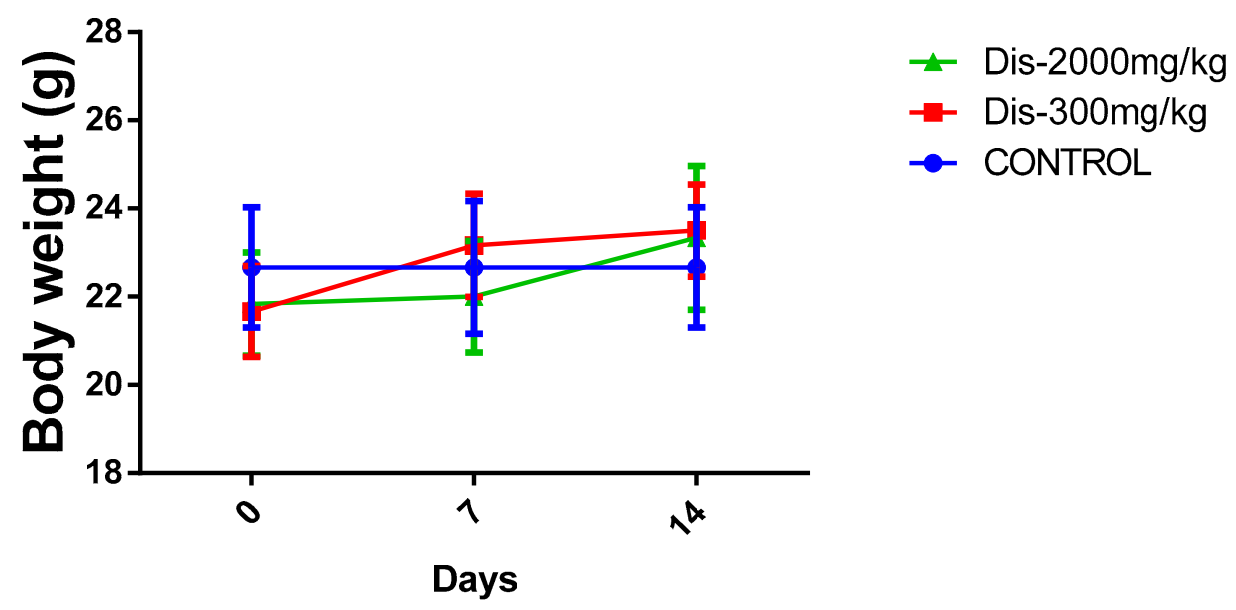

(A)
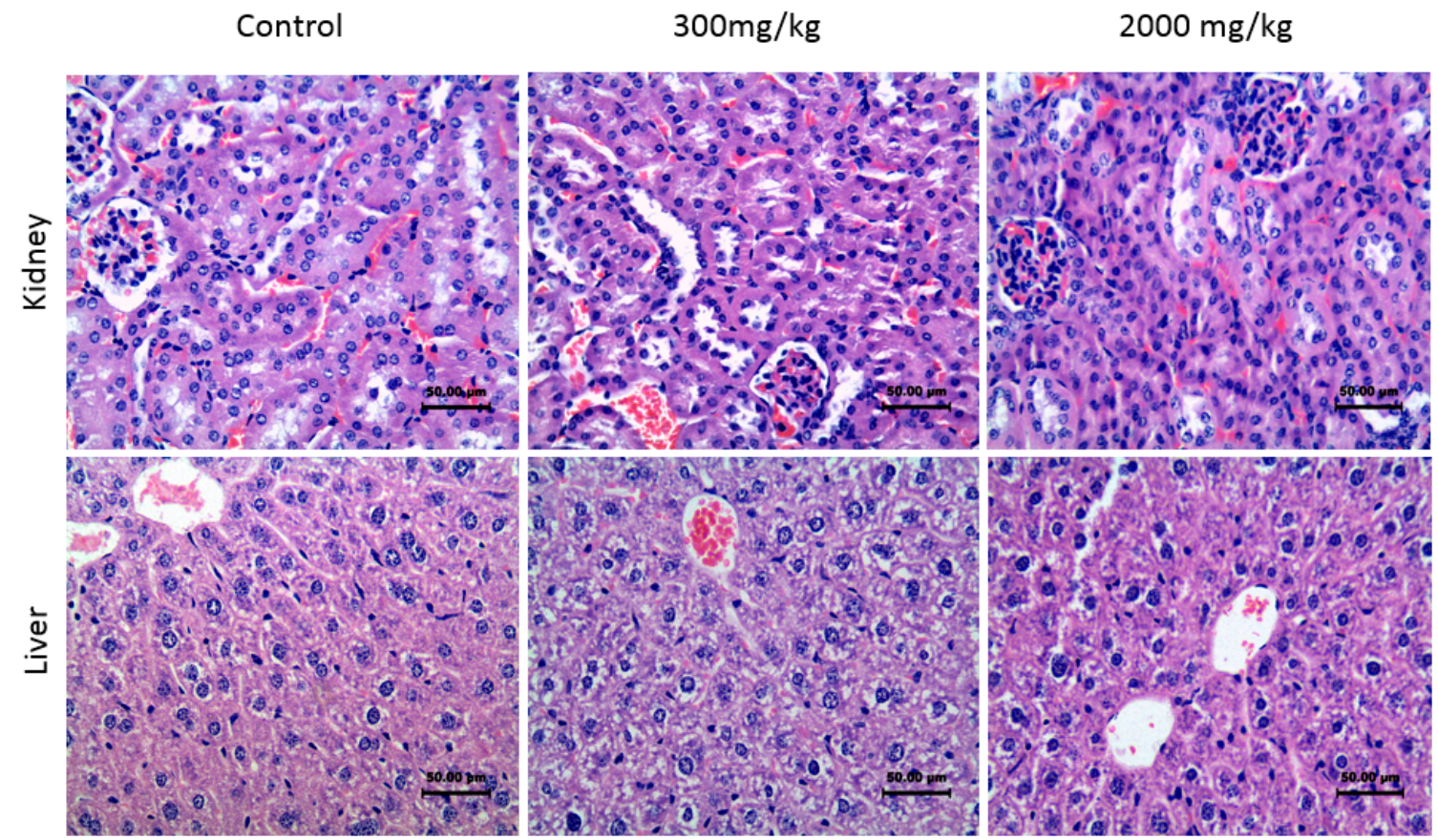

(B)

Figure 1. Toxicity effect of Dis in female ICR mice. (A) Body weight changes of mice between treated mice and untreated control during 14 days. Data were expressed as mean \pm standard deviation. (B) Toxicity effect of Dis on histological sections of liver and kidney of mice. Mice were treated with single dose of vehicle (control) or Dis (300 and $2000 \mathrm{mg} / \mathrm{kg}$ ). Kidney and liver of ICR mice were harvested after 14 days and stained with Hematoxylin and Eosin (H\&E) staining. No sign of kidney or liver tissues damage or abnormalities were observed in treated and control groups. (Magnification $\times 40)$.

On the other hand, tumor weight of the mice was measured and statistically compared between the treated and untreated groups. As presented in Figure 4, after 27 days of treatment, tumor weights were significantly lower in all treated groups compared to untreated control. Although $50 \mathrm{mg} / \mathrm{kg}$ of Dis reduced the tumor weight $(1.17 \pm 0.84 \mathrm{~g})$ significantly $(p<0.05)$, more reduction in tumor weight was observed in mice treated with the high dose of Dis $(0.62 \pm 0.29 \mathrm{~g})(p<0.01)$ and 5-Fu group $(0.57 \pm$ $0.28 \mathrm{~g})$ compared to the untreated $(2.478 \pm 0.7 \mathrm{~g})$ mice. 
Control

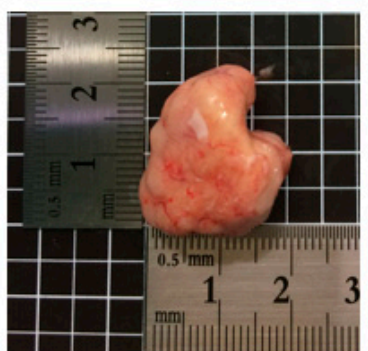

Dis-50mg/kg

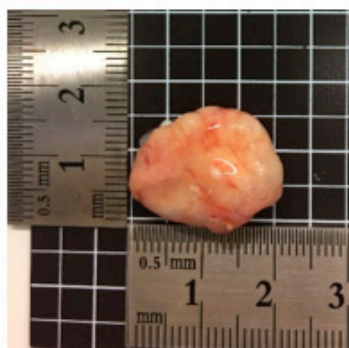

Dis-100mg/kg

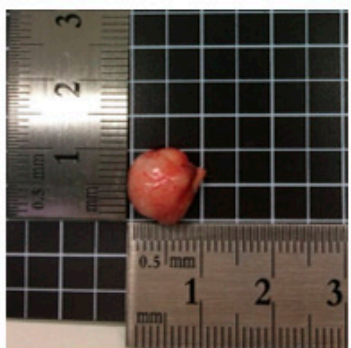

$5 \mathrm{FU}-30 \mathrm{mg} / \mathrm{kg}$

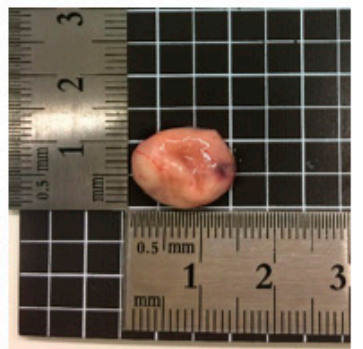

Figure 2. Tumor size of treated and untreated groups. Dis reduces the tumor size dose-dependently. 5-fluorouracil was used as a positive control.

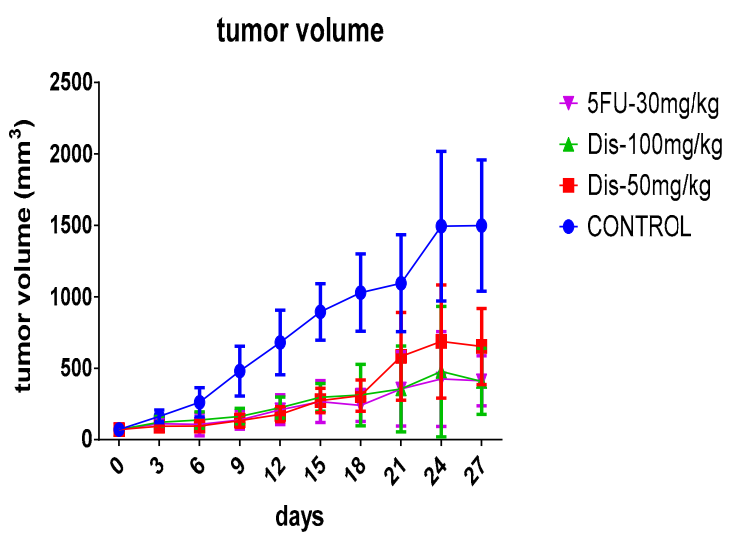

(A)

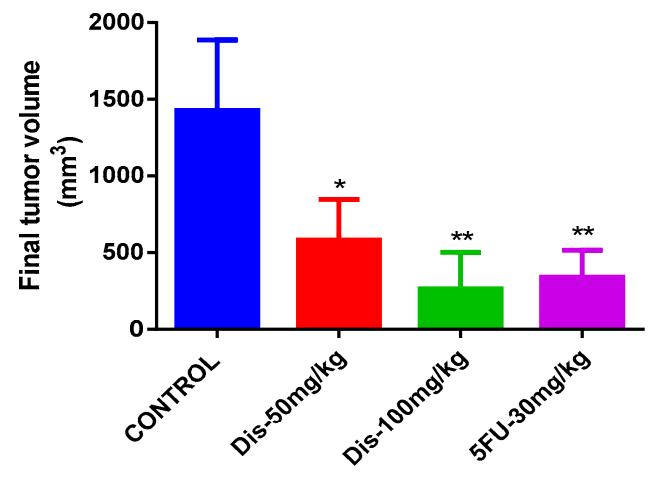

(B)

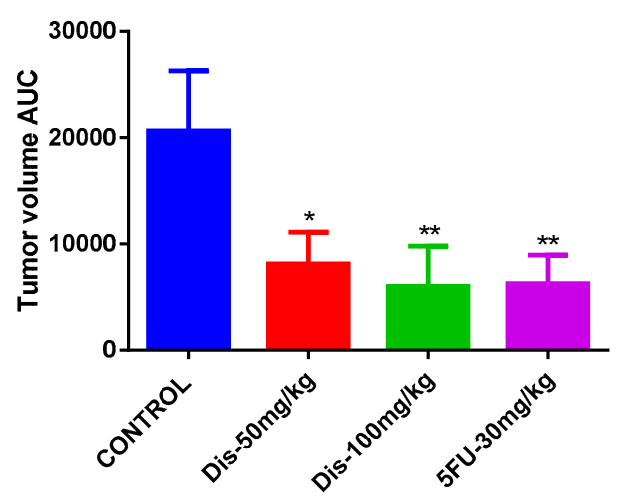

(C)

Figure 3. Tumor volume growth and final tumor volume of treated and untreated mice. (A) Tumor volume growth in control and treated groups during 27 days of treatment. (B) Final tumor volume of treated and untreated groups. (C) Area under the curve (AUC) measurement of the overall changes in tumor volume of treated mice compared to untreated group. Data were expressed as mean \pm standard deviation. ${ }^{*} p<0.05,{ }^{* *} p<0.01$ indicate significant differences compared to control.

\subsection{Apoptotic Effects of Dis in HCT-116 Xenograft Nude Mice}

Xenograft tumor tissues were used to investigate the effect of Dis on apoptosis markers, Bax and Bcl-2 [15]. Protein expression fold change of Bax in $50 \mathrm{mg} / \mathrm{kg}$ and $100 \mathrm{mg} / \mathrm{kg}$ of Dis were $1.4 \pm 0.26$ and $2.7 \pm 0.16$, respectively. While protein expression fold change of Bcl-2 were $0.56 \pm 0.26$ and $0.31 \pm$ 0.16 for the same doses. The data indicated that protein expressions of Bax were increased, whereas $\mathrm{Bcl}-2$ protein expressions were decreased dose-dependently in Dis treated mice as compared to the untreated group. Although up-regulation of Bax and down-regulation of Bcl-2 were observed in low 
dose and high dose of Dis treated mice, significant differences were only observed in high dose of Dis treated mice (Figure 5). Moreover, up-regulation of Bax (2.5 \pm 0.64$)$ in 5-Fu treated mice was slightly lower than $100 \mathrm{mg} / \mathrm{kg}$ of Dis treated mice and down regulation of Bcl-2 (0.4 \pm 0.09) in 5-Fu group was slightly higher compared to the high dose of Dis.

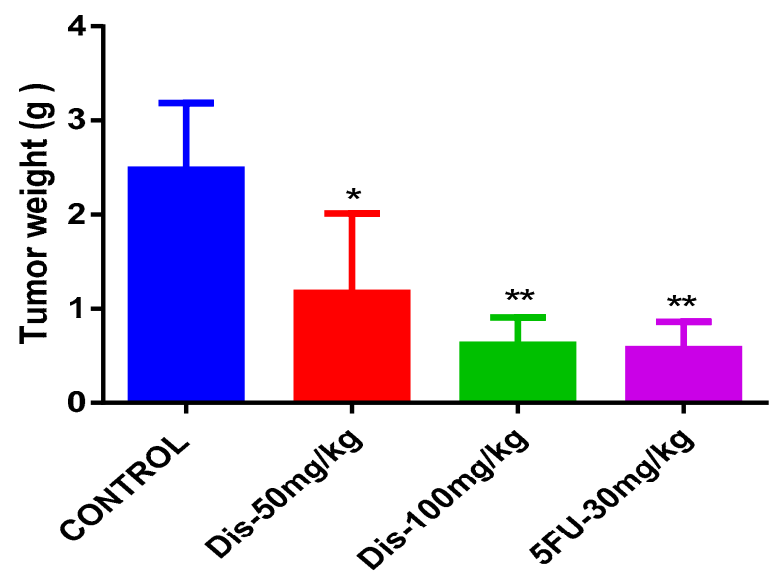

Figure 4. Tumor weight of treated and untreated mice. Tumor weight in grams after 27 days of treatment with Dis compared to control. Data were expressed as mean \pm standard deviation. ${ }^{*} p<0.05$, ** $p<0.01$ indicate significant differences compared to control.

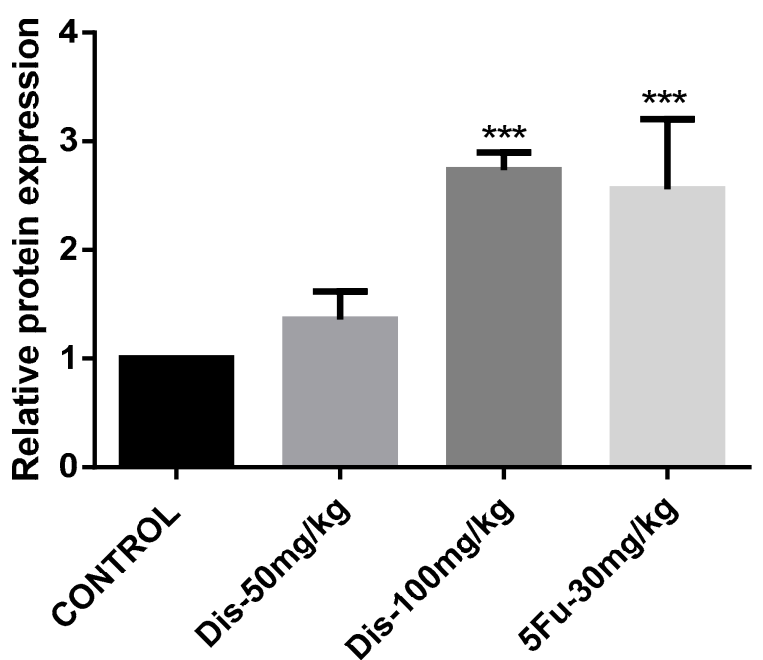

Figure 5. Cont. 


\section{$\mathrm{Bcl}-2$}

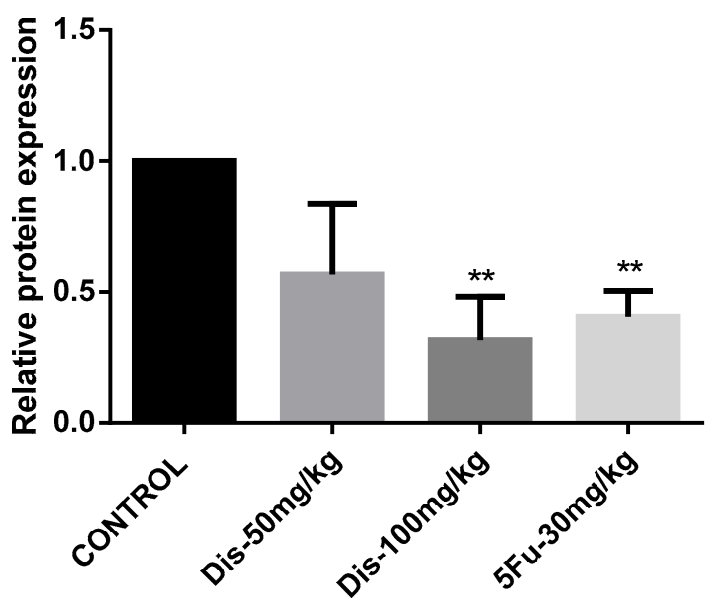

Figure 5. Dis altered apoptosis markers. Western blot analysis was carried out to evaluate the protein expression levels of Bax and Bcl-2. Results indicate that $100 \mathrm{mg} / \mathrm{kg}$ of Dis induces apoptosis through activation of Bax and inhibition of Bcl-2. $\beta$-Actin served as a loading control. Data were expressed as mean \pm standard deviation. ${ }^{* *} p<0.01,{ }^{* * *} p<0.001$, indicate significant differences compared to control.

\section{Discussion}

In this study, we investigated the anti-tumorigenesis effects of Dis, and findings showed that Dis inhibits tumor growth rate through induction of apoptosis in nude mice via overexpression of Bax and inhibition of Bcl-2. Daily administration of $100 \mathrm{mg} / \mathrm{kg}$ of Dis for 27 days reduced tumor ratio percentage by $22.3 \%$ in xenograft mice. Data of animal study showed that Dis reduces the tumor growth rate and tumor weight significantly in dose-dependent manner, however protein expression changes of Bax and Bcl-2 significantly observed only in high dose of Dis treated mice. In addition, $100 \mathrm{mg} / \mathrm{kg}$ of Dis inhibits tumor growth rate slightly better compared to the 5-Fu, however these differences were not significant. Acute toxicity results indicated that Dis is safe up to $2000 \mathrm{mg} / \mathrm{kg}$ no signs of toxicity were observed in the kidney or liver of ICR mice.

Based on tumor ratio percentage formula, the percentage of reduction in tumor growth rate among treated groups has the following order; $100 \mathrm{mg} / \mathrm{kg}$ Dis $>30 \mathrm{mg} / \mathrm{kg} 5-\mathrm{Fu}>50 \mathrm{mg} / \mathrm{kg}$ Dis. Moreover, on the sacrificing date the mean tumor weight in mice treated with $50 \mathrm{mg} / \mathrm{kg}, 100 \mathrm{mg} / \mathrm{kg}$ and 5-Fu were $1.17 \pm 0.84,0.62 \pm 0.29$ and $0.57 \pm 0.28 \mathrm{~g}$, respectively. Although tumor growth rate and tumor size was lower in high dose Dis treated mice as compared to other treated groups, tumor weight of the 5-Fu group was slightly lower compared to other groups. Even with these differences between the treatment groups, significant changes in tumor volume and tumor weight were only observed when compared to the control group.

Internal or external stimuli can induce cell programmed death or apoptosis. Targeting apoptosis signaling pathway in cancer cells is considered one of the strategies in drug discovery to explore the molecular mechanisms of potent anti-cancer agents. These agents can induce apoptosis through alteration of apoptotic proteins such as Bax, which is located in the outer membrane of mitochondria. Bax protein increases the permeability of mitochondria membrane which leads to release of other apoptotic factors and cytochrome $\mathrm{C}$, whereas inhibition of anti-apoptotic proteins such as Bcl-2 blocks their action and further enhances the cell proliferations. Release of apoptotic factors such as cytochrome $C$ leads to caspase cascades activation and initiation of apoptosis [16]. Based on our in vitro study, Dis was observed to inhibit HCT-116 cell proliferations and induce apoptosis through intrinsic and extrinsic pathways. Dis was also observed to upregulate Bax at both gene and protein levels. As a result, intrinsic apoptotic pathway was initiated due to the release of cytochrome $C$ into the cytosol fallowed by cleavage of caspase-9. Extrinsic apoptosis pathway was also activated in Dis treated cells 
with cleavage of caspase- 8 via dead domain of TNF- $\alpha /$ Fas. Furthermore, Dis caused acceleration of apoptosis through inhibition of NF- $\mathrm{kB}$ translocation into the nucleus [17].

Flavones are a subclass of flavonoids and are mainly found in chamomile, parsley, rosemary, rooibos tea, green tea, and other plants from the mint family (Lamiaceae) [18]. The most common flavones include apigenin, luteolin and diosmetin. Based on the literature, flavones may exert their anticancer effects through several possible mechanisms, such as scavenging of carcinogenic agents, modulation of cancer cell signaling, antioxidant enzymatic activities, and induction of apoptosis as well as cell cycle arrest [19]. Therefore, investigation into the anti-cancer properties of flavones as a member of flavonoids family has been attracting the attention of researchers. Besides their therapeutic potential, since flavones are present in our diet, a greater understanding of their anticancer properties might also modify our dietary habits as a step to be taken to prevent cancer.

Anti-cancer properties of Dis have been reported in several types of cancer cells. Dis induces apoptosis in PC-3 human prostate cancer cells through overexpression of Bax, P27kip1 and Foxo3 and downregulation of Bcl-2 and c-Myc [6]. Dis does not only inhibit prostate cancer cells via apoptosis but it also inhibits hepatocarcinoma and leukemia cells. Dis induces extrinsic apoptosis pathway in leukemia, whereas induction of apoptosis in hepatocarcinoma is through activation of p53 and inhibition of NF- $\mathrm{KB}$ translocation [4-11].

Previous studies showed that extracts of different plants, which contain Dis such as Anoda cristata, Fructus aurantii immaturus, Satureja khuzistanica and South American Tanacetum vulgare has in vivo anti-inflammatory and antioxidant properties [20-23]. Moreover, pretreatment of Dis attenuates acute hepatic failure in mice induced by LPS/D-GalN endotoxin through inhibition of apoptosis, inflammation and oxidative stress. In addition, Dis inhibits the phosphorylation of $I \kappa B \alpha$, and NF-kB p65 in the NF-kB signaling pathway. Pretreatment of Dis can also increase the level of radical-scavenging antioxidant enzymes such as superoxide dismutase (SOD) and catalase (CAT) in mice [24]. Yang, et al., (2017) reported that, pretreatment of Dis may protect the normal liver cells against endotoxins by inhibiting inflammation and oxidative stress factors, therefore normal cells do not enter the apoptosis and cell programmed death process.

Our in vivo results showed that the protein expression of Bax was significant increased, whereas protein expression of Bcl-2 was down-regulated in high dose Dis treated mice as compared to the control group. Therefore, we suggest that reduction in tumor size and weight of Dis treated mice could be as a result of apoptosis via activation of Bax and inhibition of Bcl-2 proteins, respectively.

\section{Materials and Methods}

\subsection{Compound and Cell Lines}

Diosmetin was obtained from Abcam (Cambridge, UK) with the purity $>98 \%$ and molecular weight of $300.26 \mathrm{~g} / \mathrm{mol}$ (Figure 6). 5-Fluorouracil (5-Fu) was purchased from MP biomedical company (MP biomedical, Illkirch-Graffenstaden, France). Human colon cancer cells (HCT-116) was obtained from ATCC, USA.

\subsection{Acute Toxicity}

Oral acute toxicity test was performed according to OECD guideline No $423[25,26]$. All animal experimental procedures were carried out according to the approval of the institutional Animal Care and Use Committee, Faculty of Medicine (FOM-IACUC), (Ethics reference No.: 2017-181205/PHAR/R/SK). The animal experiment was conducted as a stepwise procedure with the use of three female ICR mice per dose. Absence or presence of compound-related mortality of the animals dosed at each step determined the following step of either dosing of three additional animals with the same dose or dosing of three additional animals at the next higher or the next lower dose levels. Since there is no information on the toxicity of Dis, $300 \mathrm{mg} / \mathrm{kg}$ body weight was used as the starting dose according to OECD 423 guideline $[25,26]$. In total, a maximum of 18 female ICR mice (4-6 weeks old, 20-24 g) were 
used in this experiment and the grouping was as follows: Group 1: normal control, which received distilled water orally, Group 2: $300 \mathrm{mg} / \mathrm{kg}$ Dis was administered as a single dose orally, Group 3: next higher dose level of Dis (2000 mg/kg) was administered as a single dose orally. Animals were observed closely for 14 days. All the animals which survived to the end of the experiment were sacrificed on day 15 th under anesthesia using proper doses of ketamine $(100 \mathrm{mg} / \mathrm{kg})$ and xylazine $(10 \mathrm{mg} / \mathrm{kg})$. Animal weights were measured and liver and kidney were harvested for histopathological examination to evaluate signs of toxicity.

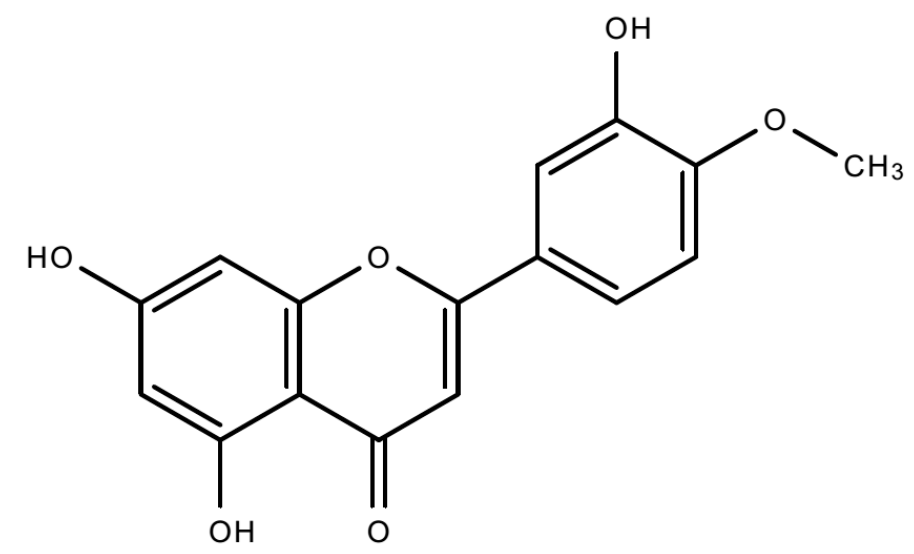

Figure 6. Chemical structure of Diosmetin.

\subsection{Human Colorectal Cancer Xenografts in Athymic Nude Mice}

A total of 24 male NCr nu/nu nude mice (4-6 weeks old, 20-22 g) were purchased from an external source with health certificate (Sterling, Singapore). Colorectal cancer HCT-116 cells $\left(2 \times 10^{6}\right.$ cells $)$ in $200 \mu \mathrm{L}$ of media were subcutaneously injected into the right flank of mice. After the volume of the tumors reached $100 \mathrm{~mm}^{3}$ [27], treatments were started by utilizing oral gavage for 4 weeks. Animals were randomly assigned to the following four groups namely; Group 1: tumor control (orally treated with the vehicle $0.5 \% \mathrm{CMC}$ ), Group 2: orally treated with Dis at $50 \mathrm{mg} / \mathrm{kg}$ (low dose) daily, Group 3: orally treated with Dis at $100 \mathrm{mg} / \mathrm{kg}$ (high dose) daily and Group 4: positive control (intraperitoneally injected with $30 \mathrm{mg} / \mathrm{kg}$ 5-Fu once per week) [27]. Tumor growth were measured two times per week using a digital caliper. Area under the curve (AUC) for the mean tumor volume versus days for each group were calculated using Graph Pad Prism, version 6.07 (Graph Pad, San Diego, CA, USA) for windows [28-30].

In order to understand the anti-tumor activity of Dis and to have a better comparison between treated and untreated mice, tumor ratio percentage was calculated according to the following formula [31]:

$$
\text { Tumor ratio precentage }=\mathrm{T} / \mathrm{C} \times 100 \text {, }
$$

where, $\mathrm{T}$ is the mean tumor volume of treated mice on the sacrificing date, and $\mathrm{C}$ is the mean tumor volume of control group.

On the sacrificing date, ketamine $(100 \mathrm{mg} / \mathrm{kg})$ and xylazine $(10 \mathrm{mg} / \mathrm{kg})$ were injected as a single dose intraperitoneally (IP). The tumors were harvested, washed and weighted. Tumor samples were kept at $-80^{\circ} \mathrm{C}$ for western blot assay.

\subsection{Western Blot}

Lysis buffer (50 mM Tris-HCL pH 8.0, $120 \mathrm{mM} \mathrm{NaCl,} \mathrm{0.5 \%} \mathrm{NP-40,} 1$ mM PMSF) was added to the tumor specimens and homogenized using homogenizer (Cole-Parmer, USA). Lysates were then centrifuged for $30 \mathrm{~min}$ at $15,000 \times g$ and $4{ }^{\circ} \mathrm{C}$. Supernatant was collected and the protein concentration was quantified via Pierce BCA protein assay kit (Thermo Scientific ${ }^{\mathrm{TM}}$, Pittsburgh, PA, USA) [32]. An amount of $80 \mu \mathrm{g}$ of protein were separated by $10 \%$ SDS PAGE, then transferred to a polyvinylidene 
difluoride (PVDF) membrane (Bio-Rad, USA), then were blocked with 3\% skim milk in TBS-Tween buffer 7 (0.12 M Tris-base, $1.5 \mathrm{M} \mathrm{NaCl}, 0.1 \%$ Tween 20) for $1 \mathrm{~h}$ at room temperature, and were incubated with the primary antibody ( $\beta$-actin (1:10,000), Bcl-2 (1:1000) and Bax (1:1000)) for $2 \mathrm{~h}$. Then horseradish peroxidase conjugated secondary antibody was added and incubated for $2 \mathrm{~h}$ at room temperature. The bound antibody was detected with peroxidase-conjugated secondary antibody followed by chemiluminescence detection (ECL System) (Bio-Rad, Hercules, CA, USA) and exposed by UVP (Bio-Rad, Hercules, CA, USA).

\subsection{Statistical Analysis}

All the data were expressed as mean \pm standard deviation (SD) and statistical analyses was performed using one-way analysis of variance (ANOVA) with Tukey's multiple comparisons. Data were analyzed with Graph Pad Prism, version 6.07 for windows. The values of $p<0.05$ were considered significant.

\section{Conclusions}

In conclusion, Dis is a potent anti-tumor compound, which acts by targeting apoptosis and inhibiting colon cancer tumor growth in nude mice. Our results indicated that Dis is able to reduce the tumor weight and tumor growth rate in nude mice and is safe up to $2000 \mathrm{mg} / \mathrm{kg}$. Moreover, overexpression of Bax and suppression of Bcl-2 illustrates that the mechanism of tumor suppression of Dis might be through induction of apoptosis. These results need further pharmacokinetic and pharmacodynamics studies as well as further toxicity evaluation in order to assess whether Diosmetin could be introduced as a therapeutic agent against human colon cancer with a relatively safe profile.

Author Contributions: M.A.A., Z.M., and S.K. designed the study; S.K. carried out the experiment; M.A.A., Z.M., A.S., and S.K. analyzed the data; M.A.A., Z.M., A.S., and S.K. interpreted the findings; S.K. drafted the manuscript and all authors reviewed the manuscript and approved the final version for publication.

Funding: The authors would like to thank the University of Malaya, Malaysia, for supporting this study through BKP grant No. BKS102-2017.

Conflicts of Interest: The authors declare no conflict of interest.

\section{References}

1. Arnold, M.; Sierra, M.S.; Laversanne, M.; Soerjomataram, I.; Jemal, A.; Bray, F. Global patterns and trends in colorectal cancer incidence and mortality. Gut 2016, 66, 683-691. [CrossRef] [PubMed]

2. Focaccetti, C.; Bruno, A.; Magnani, E.; Bartolini, D.; Principi, E.; Dallaglio, K.; Bucci, E.O.; Finzi, G.; Sessa, F.; Noonan, D.M. Effects of 5-fluorouracil on morphology, cell cycle, proliferation, apoptosis, autophagy and ROS production in endothelial cells and cardiomyocytes. PLoS ONE 2015, 10, e0115686. [CrossRef] [PubMed]

3. Koosha, S.; Alshawsh, M.A.; Looi, C.Y.; Seyedan, A.; Mohamed, Z. An association map on the effect of flavonoids on the signaling pathways in colorectal cancer. Int. J. Med. Sci. 2016, 13, 374. [CrossRef] [PubMed]

4. AlAjmi, M.F.; Rehman, M.T.; Hussain, A.; Rather, G.M. Pharmacoinformatics approach for the identification of Polo-like kinase-1 inhibitors from natural sources as anti-cancer agents. Int. J. Biol. Macromol. 2018, 116, 173-181. [CrossRef] [PubMed]

5. Androutsopoulos, V.P.; Mahale, S.; Arroo, R.R.; Potter, G. Anticancer effects of the flavonoid diosmetin on cell cycle progression and proliferation of MDA-MB 468 breast cancer cells due to CYP1 activation. Oncol. Rep. 2009, 21, 1525-1528. [PubMed]

6. Oak, C.; Khalifa, A.; Isali, I.; Bhaskaran, N.; Walker, E.; Shukla, S. Diosmetin suppresses human prostate cancer cell proliferation through the induction of apoptosis and cell cycle arrest. Int. J. Oncol. 2018, 53, 835-843. [CrossRef] [PubMed]

7. Xu, Z.; Yan, Y.; Xiao, L.; Dai, S.; Zeng, S.; Qian, L.; Wang, L.; Yang, X.; Xiao, Y.; Gong, Z. Radiosensitizing effect of diosmetin on radioresistant lung cancer cells via Akt signaling pathway. PLoS ONE 2017, 12, e0175977. [CrossRef] [PubMed] 
8. Roma, A.; Rota, S.G.; Spagnuolo, P.A. Diosmetin Induces Apoptosis of Acute Myeloid Leukemia Cells. Mol. Pharm. 2018, 15, 1353-1360. [CrossRef]

9. Liu, J.; Wen, X.; Liu, B.; Zhang, Q.; Zhang, J.; Miao, H.; Zhu, R. Diosmetin inhibits the metastasis of hepatocellular carcinoma cells by downregulating the expression levels of MMP-2 and MMP-9. Mol. Med. Rep. 2016, 13, 2401-2408. [CrossRef]

10. Liu, B.; Shi, Y.; Peng, W.; Zhang, Q.; Liu, J.; Chen, N.; Zhu, R. Diosmetin induces apoptosis by upregulating p53 via the TGF- $\beta$ signal pathway in HepG2 hepatoma cells. Mol. Med. Rep. 2016, 14, 159-164. [CrossRef]

11. Qiao, J.; Liu, J.; Jia, K.; Li, N.; Liu, B.; Zhang, Q.; Zhu, R. Diosmetin triggers cell apoptosis by activation of the p53/Bcl-2 pathway and inactivation of the Notch3/NF-kB pathway in HepG2 cells. Oncol. Lett. 2016, 12, 5122-5128. [CrossRef] [PubMed]

12. Xie, Y.Y.; Yuan, D.; Yang, J.Y.; Wang, L.H.; Wu, C.F. Cytotoxic activity of flavonoids from the flowers of Chrysanthemum morifolium on human colon cancer Colon205 cells. J. Asian Nat. Prod. Res. 2009, 11, 771-778. [CrossRef] [PubMed]

13. Lin, A.S.; Lin, C.R.; Du, Y.C.; Lübken, T.; Chiang, M.Y.; Chen, I.H.; Wu, C.C.; Hwang, T.L.; Chen, S.L.; Yen, M.H. Acasiane A and B and farnesirane A and B, diterpene derivatives from the roots of Acacia farnesiana. Planta Med. 2009, 75, 256-261. [CrossRef] [PubMed]

14. Kuntz, S.; Wenzel, U.; Daniel, H. Comparative analysis of the effects of flavonoids on proliferation, cytotoxicity, and apoptosis in human colon cancer cell lines. Eur. J. Nutrition 1999, 38, 133-142. [CrossRef]

15. Watson, A. Apoptosis and colorectal cancer. Gut 2004, 53, 1701-1709. [CrossRef] [PubMed]

16. Elmore, S. Apoptosis: A review of programmed cell death. Toxicol. Pathol. 2007, 35, 495-516. [CrossRef] [PubMed]

17. Koosha, S.; Mohamed, Z.; Sinniah, A.; Alshawsh, M.A. Investigation into the Molecular Mechanisms underlying the Anti-proliferative and Anti-tumorigenesis activities of Diosmetin against HCT-116 Human Colorectal Cancer. Sci. Rep. 2019, 9, 5148. [CrossRef] [PubMed]

18. Hostetler, G.L.; Ralston, R.A.; Schwartz, S.J. Flavones: Food sources, bioavailability, metabolism, and bioactivity. Adv. Nut. 2017, 8, 423-435. [CrossRef] [PubMed]

19. Surh, Y.J. Cancer chemoprevention with dietary phytochemicals. Nat. Rev. Cancer 2003, 3, 768-780. [CrossRef]

20. Juarez-Reyes, K.; Brindis, F.; Medina-Campos, O.N.; Pedraza-Chaverri, J.; Bye, R.; Linares, E.; Mata, R. Hypoglycemic, antihyperglycemic, and antioxidant effects of the edible plant Anoda cristata. J. Ethnopharmacol. 2015, 161, 36-45. [CrossRef]

21. Liu, X.Y.; Fan, M.L.; Wang, H.Y.; Yu, B.Y.; Liu, J.H. Metabolic profile and underlying improved bio-activity of Fructus aurantii immaturus by human intestinal bacteria. Food Funct. 2017, 8, 2193-2201. [CrossRef] [PubMed]

22. Malmir, M.; Gohari, A.R.; Saeidnia, S.; Silva, O. A new bioactive monoterpene-flavonoid from Satureja khuzistanica. Fitoterapia 2015, 105, 107-112. [CrossRef] [PubMed]

23. Schinella, G.R.; Giner, R.M.; Recio, M.C.; Mordujovich de Buschiazzo, P.; Rios, J.L.; Manez, S. Anti-inflammatory effects of South American Tanacetum vulgare. J. Pharm. Pharmacol. 1998, 50, 1069-1074. [CrossRef] [PubMed]

24. Yang, Y.; Gong, X.B.; Huang, L.G.; Wang, Z.X.; Wan, R.Z.; Zhang, P.; Zhang, Q.Y.; Chen, Z.; Zhang, B.S. Diosmetin exerts anti-oxidative, anti-inflammatory and anti-apoptotic effects to protect against endotoxin-induced acute hepatic failure in mice. Oncotarget 2017, 8, 30723-30733. [CrossRef] [PubMed]

25. Li, F.; Li, Y.; Li, Q.; Shi, X.; Guo, Y. Acute and Subacute Oral Toxicity Evaluation of Eriobotrya japonica Leaf Triterpene Acids in ICR Mice. Evid.-Based Complement. Alternat. Med. 2017, 2017, 4837839. [CrossRef] [PubMed]

26. Jonsson, M.; Jestoi, M.; Nathanail, A.V.; Kokkonen, U.M.; Anttila, M.; Koivisto, P.; Karhunen, P.; Peltonen, K. Application of OECD Guideline 423 in assessing the acute oral toxicity of moniliformin. Food Chem. Toxicol. 2013, 53, 27-32. [CrossRef] [PubMed]

27. Shentu, S.; Aggarwal, B.B.; Krishnan, S. Curcumin Sensitizes Human Colorectal Cancer Xenografts in Nude Mice to;-Radiation byTargeting Nuclear Factor-KB^ Regulated Gene Products. Clin. Cancer Res. 2008, $14,7$.

28. Pyo, J.H.; Byeon, S.J.; Lee, H.; Min, Y.W.; Min, B.H.; Lee, J.H.; Kim, K.M.; Ahn, H.S.; Kim, K.; Choi, Y.H. Measurement of tumor volume is not superior to diameter for prediction of lymph node metastasis in early gastric cancer with minute submucosal invasion. Oncotarget 2017, 8, 113758. [CrossRef] 
29. Corwin, W.L.; Ebrahimi-Nik, H.; Floyd, S.M.; Tavousi, P.; Mandoiu, I.I.; Srivastava, P.K. Tumor Control Index as a new tool to assess tumor growth in experimental animals. J. Immunol. Methods 2017, 445, 71-76. [CrossRef]

30. Aipire, A.; Li, J.; Yuan, P.; He, J.; Hu, Y.; Liu, L.; Feng, X.; Li, Y.; Zhang, F.; Yang, J. Glycyrrhiza uralensis water extract enhances dendritic cell maturation and antitumor efficacy of HPV dendritic cell-based vaccine. Sci. Rep. 2017, 7, 43796. [CrossRef]

31. Hather, G.; Liu, R.; Bandi, S.; Mettetal, J.; Manfredi, M.; Shyu, W.C.; Donelan, J.; Chakravarty, A. Growth Rate Analysis and Efficient Experimental Design for Tumor Xenograft Studies: Supplementary Issue: Array Platform Modeling and Analysis (A). Cancer Inf. 2014, 13, CIN. S13974. [CrossRef] [PubMed]

32. Kunnumakkara, A.B.; Guha, S.; Krishnan, S.; Diagaradjane, P.; Gelovani, J.; Aggarwal, B.B. Curcumin potentiates antitumor activity of gemcitabine in an orthotopic model of pancreatic cancer through suppression of proliferation, angiogenesis, and inhibition of nuclear factor-kB-regulated gene products. Cancer Res. 2007, 67, 3853-3861. [CrossRef] [PubMed]

Sample Availability: Samples of the compounds are available from the authors.

(C) 2019 by the authors. Licensee MDPI, Basel, Switzerland. This article is an open access article distributed under the terms and conditions of the Creative Commons Attribution (CC BY) license (http://creativecommons.org/licenses/by/4.0/). 